\title{
Az energiamentes édesítőszerek alkalmazásának hatása klinikai vizsgálatok, in vitro és állatkísérletek eredményei alapján
}

\author{
Szúcs Zsuzsanna ${ }^{1}$ - Ábel Tatjána dr. $^{2}$ - Lengyel Gabriella dr. ${ }^{3}$ \\ ${ }^{1}$ Magyar Dietetikusok Országos Szövetsége, Budapest \\ ${ }^{2}$ Magyar Honvédség Egészségügyi Központ, Szakrendelő Intézet, Budapest \\ ${ }^{3}$ Semmelweis Egyetem, Általános Orvostudományi Kar, II. Belgyógyászati Klinika, Budapest
}

\begin{abstract}
Az energiamentes édesítőszerek fogyasztása az elmúlt néhány évtizedben előtérbe került, mivel az édes ízt kalóriabevitel nélkül képesek biztosítani és ezáltal támogathatják a testtömeg optimális szinten tartását. Ez az előnyös hatás azonban gyakran megkérdőjeleződik, ugyanis az energiamentes édesítőszereket összefüggésbe hozzák az édes íz iránti vágy fenntartásával, illetve fokozásával és az édességek, édes italok túlzott fogyasztásával. A legújabb vizsgálatok azonban nem találtak pozitív összefüggést az energiamentes édesítőszerek használata és az édes íz iránti sóvárgás között. A randomizált kutatások azt igazolták, hogy fogyasztásuk inkább mérsékli, mint emeli a cukortartalmú élelmiszerek fogyasztását, jótékony hatást fejtenek ki az étrend minőségére és segítik a testtömegkontrollt. Számos, elsősorban sejttenyészeteken végzett, illetve állatkísérletes vizsgálat felveti az energiamentes édesítőszerek jótékony anyagcserehatásait, például a kisebb mértékű ectopiás zsír felszaporodását a máj- és izomszövetben a kontrollcsoporthoz képest. Ezek mellett megfigyelték a fokozott adipogenezis, illetve a csökkent lipolízis kialakulását is. Orv. Hetil., 2016, 157(Szuppl. 1), 3-7.
\end{abstract}

Kulcsszavak: energiamentes édesítőszerek, édes íz, zsírszövet

\section{Effects of low calorie sweeteners based on data from clinical trials, in vitro and animal studies}

Low calorie sweeteners are used by many consumers as they can provide the sweet taste without calories and, therefore, they may have a beneficial effect on weight management. These positive outcomes are often questioned and accused of keeping up or increasing a liking for sweetness and leading to overconsumption of sugar containing food and beverages. The most recent studies failed to find any positive correlation between usage of low calorie sweeteners and craving for sweet taste. In randomized controlled trials consumption of low calorie sweeteners have accompanied with lower intake of sugar containing food, higher healthy eating index and better weight management. Several laboratory trials on cell cultures and animal studies found a link between the usage of low calorie sweeteners and positive metabolic effects, e.g. smaller ectopic fat deposits in the fat and liver tissue versus controll group. In addition, increased adipogenesis and reduction of lipolysis were also observed.

Keywords: low calorie sweeteners, sweet taste, adiposity

Szücs, Zs., Ábel, T., Lengyel, G. [Effects of low calorie sweeteners based on data from clinical trials, in vitro and animal studies]. Orv. Hetil., 2016, 157(Suppl. 1), 3-7.

(Beérkezett: 2016. március 7.; elfogadva: 2016. március 24.) 
Az energiamentes édesítőszerek (mint például a szukralóz, a sztívia vagy az aszpartám) fogyasztása, elsősorban a túlsúly és az elhízás, illetve a diabetes „térhódításával” egyre inkább beépül a hétköznapi étrendbe. Ugyanakkor ezen élelmiszer-adalékanyagok biztonságosságával, táplálkozás-élettani hatásával kapcsolatban számos aggály és félelem merül fel. Összefüggésbe hozzák őket az étvágy, az édes íz iránti sóvárgás növekedésével, ennek következtében pedig a túlsúly és elhízás, a diabetes, a cardiovascularis betegségek emelkedett kockázatával. Az említett aggályok által felvetett kérdések extenzív kutatások tárgyát képezik szerte a világon. E cikkben az energiamentes édesítőszerekkel kapcsolatban felmerült néhány nyitott kérdésre keressük a választ az édes íz iránti vágy, az étrend minőségére gyakorolt esetleges hatás, az oxidatív stressz, valamint a zsírszövet anyagcseréjének szempontjából.

\section{Az energiamentes édesítószerek hatása az édes íz iránti vágyra}

Az édes íz kedvelése és az édes ízú élelmiszerek, italok fogyasztása mögött meghúzódó biológiai mechanizmusok a mai napig a táplálkozástudomány élénken kutatott területe. A teória, amely szerint az édesítőszerek fokozzák az étvágyat és az élelmiszer-fogyasztást, az 1980-as években született John Blundellnek és munkatársainak köszönhetően [1-5]. Blundell elmélete szerint az olyan esetekben, amikor az édes íz érzékeléséhez nem párosul energiafelvétel, mint az energiamentes édesítőszerek fogyasztásakor, elmarad az érzékszervi élmény további táplálékfelvételt csökkentő hatása, például az alliesthaesia, vagyis az étel attraktivitásának mérséklődése.

Az elmúlt néhány évtizedben elvégzett kutatások (megfigyeléses, laboratóriumi és randomizált kontrollcsoportos vizsgálatok), illetve ezek eredményeinek metaanalízise bizonyította, hogy Blundell teóriájával ellentétben az energiamentes édesítőszerek fogyasztása csökkenti a kalóriafelvételt, ezáltal pedig hozzájárulhat a testtömegkontrollhoz [6].

Laboratóriumi vizsgálatokban cukorral, illetve energiamentes édesítőszerrel készült ital fogyasztása után a résztvevők a tesztital ugyanolyan mértékű kedveléséról számoltak be, valamint nem volt különbség az édes íz iránti vágy mértékében sem [7]. Számos randomizált, kontrollcsoportos vizsgálat tárgyát képezi az energiamentes édesítőszerek hatása az édes íz iránti vágyra, illetve az édes ízú élelmiszerek, italok fogyasztására a testtömegtartás időszakában. A súlycsökkenés, többek között egyes hormonok elválasztásában bekövetkező változások - például a leptin szintjének csökkenése, illetve a ghrelinszint növekedése - miatt érzékenyebbé tesz az ízek érzékelésére [8,9]. Emiatt az energiamentes édesítőszerek fogyasztásától függetlenül, a testtömegcsökkentő étrend önmagában párosul az édes íz iránti vágy intenzitásának növekedésével. Obes felnőttek részvételével végzett 6 hónapos testtömegcsökkentő étrendi intervenció során a cukorral ízesített italok vízre, illetve energiamentes édesítôvel készült italra történő cseréje után a cukorfogyasztás szignifikáns mértékü csökkenését figyelték meg mindkét csoportban [10]. Ezen belül a cukorral ízesített kávé, tea fogyasztásának csökkenése egyöntetűen megjelent mindkét kohorsz esetében. Emellett azonban azok, akik energiamentes édesítőszert fogyasztottak, még édességfogyasztásukat is mérsékelték, valamint összességében kevesebb hozzáadott kalóriatartalmú édesítőszert használtak. Egy másik, szintén elhízott felnőttek körében végzett vizsgálatban az energiamentes italt fogyasztók körében nagyobb mértékü étvágycsökkenésről számoltak be a vízhez képest, bár ez a különbség nem volt szignifikáns mértékű [11]. A többségében egészséges testtömegü, iskolás korú gyermekek részvételével, 18 hónapon át tartó DRINK (Double-blind, Randomized INtervention study in Kids) studyban, bár az érzékszervi bírálat során a résztvevők különbséget tudtak tenni a cukorral, illetve energiamentes édesítőszerrel ízesített ital között, annak ízletességét, illetve telítőértékét egyformának ítélték, továbbá nem volt megfigyelhető egyéb forrásból történő kompenzáció az édesítőszert fogyasztó csoport esetében [12].

A fenti eredmények valószínúsítik, hogy az energiamentes édesítőszerek használata hatékonyan képes kielégíteni az édes íz iránti vágyat, mindeközben hozzájárulhat az energiafelvétel csökkentéséhez, a testtömegkontrollhoz.

\section{Az energiamentes édesítőszerek fogyasztása és az étrend minősége}

Az édes íz iránti sóvárgás, illetve annak kedvelésének kérdése az energiamentes édesítőszerekkel összefüggésben nem választható szét annak az étrend összetételére gyakorolt hatásától.

A 12 ezer, 45-60 éves felnőtt táplálkozási szokásait és egészségparamétereit 8 évig követő kettős vak, randomizált kontrollcsoportos vizsgálatban, a SuViMax studyban, megközelítőleg a részt vevő férfiak 20, míg a nők 30 százaléka használt alkalmilag vagy rendszeresen energiamentes édesítőszereket [13]. A vizsgált személyek BMIje 1,5 ponttal magasabb volt az édesítőszert nem fogyasztók csoportjáénál, éhomi vércukor- és trigliceridszintjük is magasabbnak, teljes napi energiafelvételük alacsonyabbnak bizonyult, valamint szignifikáns mértékben kevesebb cukrot fogyasztottak. Étrendjükben kevesebb édesség, illetve burgonya, valamint több joghurt szerepelt, mint az édesítőszereket nem használókéban. Ezek a jellegzetességek arra utalhatnak, hogy az energiamentes édesítőszereket fogyasztók számára a testtömegkontroll problémát jelent, amelyet élelmiszer-választásukkal, a felvett cukor mennyiségének mérséklésével is igyekeznek megoldani. Az eredmények szintén meggyőzően cáfolják azt a véleményt, amely szerint az energiamentes édesítőszerek növelik az étvágyat, valamint a cukor és az édes íz iránti sóvárgást. 
Drewnowski és Rehm 2014-ben, az 1999-2008 között, több mint 22 ezer résztvevőn végzett országos reprezentatív táplálkozási és egészségi állapot felmérés, a NHANES (National Health and Nutrition Examination Survey) táplálkozási szokásokra vonatkozó adatait elemezte [14]. Az étrend minőségét a „healthy eating index" (HEI) 2005 alapján osztályozták. Az energiamentes édesítőszerek fogyasztóit magasabb HEI jellemezte, mint azokat, akik nem használtak édesítőszereket. A különbség elsősorban a keményített zsiradékok, hozzáadott cukrok, valamint az alkohol alacsonyabb mértékú fogyasztásából eredt, valamint étrendjük több zöldséget, teljes értékű gabonát, sovány tejterméket tartalmazott, azonban több telített zsírt és sót fogyasztottak az édesítőket nem használó alanyoknál.

Piernas és mtsai szintén a már említett NHANES 2003-2010 közötti szakaszának 34393 egyén táplálékfelvételére vonatkozó adatát, valamint a 2000 és 2010 között a Nielsen Homescan adatbázisban szereplő 140352 amerikai háztartás élelmiszer-vásárlásához társuló információt elemezték [15]. Ennek részeként összehasonlítást végeztek a cukortartalmú és/vagy csökkentett kalóriatartalmú, illetve kalóriamentes italokat fogyasztók táplálkozási mintái, valamint azok étrendi jellemzői között, akik egyáltalán nem fogyasztottak ízesített italokat. Eszerint bármilyen ízesített ital vásárlása, illetve fogyasztása a teljes értékü fehérjékben gazdag élelmiszerek (például tojás, húsok, halak), sós snackek, kész- és gyorséttermi ételek és desszertek magasabb fogyasztásával párosult. Emellett az energiamentes édesítőszerrel készült italok fogyasztása esetén magasabbnak bizonyult a zöldségek, gyümölcsök, továbbá a fogyasztásra kész gabonatermékek bevitele. A Homescan adatai alapján, a NHANES adataival ellentétben, az energiamentes édesítőszerrel készült italokat fogyasztók esetében a cukortartalmú édességek vásárlása gyakoribbnak bizonyult a többi vizsgált csoporthoz képest. Pozitívumként említhető, hogy az energiamentes édesítószerrel készült italok fogyasztása, amennyiben egy tudatosan összeállított (például teljes értékű élelmiszerekben, zöldségekben, gyümölcsökben gazdag) étrend részeként jelent meg, csökkentette a kardiometabolikus betegségek kialakulását [16]. A Homescan adatai szerint azok az egyszemélyes háztartások, amelyek energiamentes édesítőszerrel készült italokat vásároltak, a választott élelmiszerek energiatartalma vonatkozásában helyesebb fogyasztói döntéseket hoztak [17]. Mindazonáltal Piernas és mtsai kutatásainak végső megállapításai igen ellentmondásosak az energiamentes édesítőszerrel készült italok fogyasztóinak étrendi minóségével kapcsolatban. Hiszen, bár megfigyelték ennél a fogyasztói csoportnál a pozitív táplálkozás-élettani hatású gyümölcsök és zöldségek bőséges fogyasztásával jellemezhető tudatos táplálkozási minta megjelenését, de ugyanakkor jellemzőnek bizonyult a sós snackek és édesítőszerrel készült desszertek, kész-, illetve gyorséttermi ételek fogyasztása is [15].
Biztosan látható, hogy az energiamentes édesítőszereknek az étrend minóségére, összetételére gyakorolt hatásának vonatkozásában még további, a helyi élelmiszerválasztékot, lokális táplálkozási szokásokat, hagyományokat is figyelembe vevő vizsgálatok szükségesek.

\section{$\mathrm{Az}$ energiamentes édesítőszerek és az édes ízt érző receptorok}

Az eddig megjelent állatkísérletes eredmények azt mutatják, hogy a szukralóz, az aszpartám és az aceszulfám-K a bélben lévő, édes ízt érző receptorok aktivitásának növelésével fokozzák a nátrium-glükóz kotranszporter-1 (SGLT-1) expresszióját és ezzel mérsékelhetik a postprandialis vércukor szintjét [18-20].

$\mathrm{Az}$ energiamentes édesítőszerek a bélben termelődő, glükózhomeosztázis fiziológiás szabályozásában részt vevő glükagonszerű peptid-1 (glukagon-like peptide-1 - GLP-1) szintjére gyakorolt hatásával kapcsolatban megjelent eredmények egymásnak ellentmondóak. Egészséges felnőttek esetében a szukralóz- és az aceszulfám-K-tartalmú üdítőital fogyasztását követően a GLP-1 szintjének szignifikáns növekedését és ezáltal a postprandialis glükóz emelkedésének mérséklődését mutatták ki [21]. Ezzel szemben az édesítőszereket (aszpartám, szukralóz, szacharin, sztívia, aceszulfám-K) külön-külön, intragastricus infúzióban, egészséges személyeknek adva nem találtak akut GLP-1-koncentráció-változást [2225].

Az energiamentes édesítőszerek intracelluláris, enterocytákban történő hatása is aktív kutatás tárgyát képezi. $\mathrm{Az}$ aceszulfám-K patkánybélsejt-tenyészetben (Caco-2, RIE-1, IEC-6) a GLUT-2 basolateralis membránból az apicalis membránba történő transzlokációjával növeli a glükóz intracelluláris felvételét [26].

További vizsgálatok szükségesek tehát annak megítélésére, hogy az energiamentes édesítőszerekkel készült ételek, italok rendszeres fogyasztása milyen hatást gyakorol a bélben lévő édes ízt érző receptorokra és ezáltal a szénhidrát-anyagcserére.

\section{Az energiamentes édesítőszerek és az oxidatív stressz}

Sztívia hatására 2-es típusú diabeteses patkányokban mérséklődött a máj- (ALT-, AST-szintek csökkentek) és a vese- (GFR-érték csökkenése mérséklődött) károsodás mértéke [27]. Emellett a vizsgálók azt találták, hogy a sztívia a patkányokban in vivo és in vitro is antioxidáns hatással (például a lipidperoxidáció mértéke csökkent) rendelkezett [27, 28]. Az aszpartám az egerek agyában enyhén emeli, a májában azonban nem változtatja meg az oxidatív stresszt [29]. Ennek az eredménynek azonban nem ismert, hogy van-e emberekben jelentősége. 


\section{Az energiamentes édesítőszerek és a zsírszövet}

Az állatkísérletek adatai azt mutatták, hogy az energiamentes édesítószerek adása a szukrózhoz képest szignifikánsan alacsonyabb vércukorszintet, zsírszövet- (adipocyták mérete) és testsúlynövekedést okoznak $(\mathrm{p}<0,05)$ $[30,31]$. Az egyik vizsgálatban az egereknek, kontrollcsoportként, vizet adtak [30]. Az eredményeik szerint az energiamentes édesítószereket fogyasztók és a kontrollcsoport között nem volt szignifikáns különbség az átlagos táplálékfelvétel és a testsúly változásában sem $(\mathrm{p}>0,1)$.

$\mathrm{Az}$ aszpartám a 3T3-Ll praeadipocyta-sejttenyészetben csökkentette a lipidakkumulációt, szignifikánsan mérsékelte a peroxiszómaproliferációt aktiváló receptor $\gamma$ (PPAR- $\gamma$ ) és a szabad zsírsavat kötő fehérje 4 (fatty acidbinding protein 4 - FABP4) expresszióját is, amelyeknek következtében fokozta az adipocyták differenciálódását és ezzel az elhízás mérséklődését is [32].

A sztívia 3T3-Ll adipocytákban fokozta a glükóztranszporter-4 aktivitását, amelynek hatására a glükóz a sejtekbe kerül [33]. Az eredményeik azt mutatták, hogy a sejttenyészetben a sztívia inzulinhoz hasonló hatással rendelkezik.

\section{Következtetések}

Az energiamentes édesítőszerek táplálkozási élettani hatásaival, használatuk esetleges kockázataival, előnyeivel kapcsolatban egyre több kutatási eredmény áll rendelkezésünkre. A pillanatnyilag elérhető tudományos eredmények (felnőttek, gyermekek, egészséges testtömegü és elhízott egyének részvételével végzett vizsgálatok megállapításai) alapján bizonyítottnak túnik, hogy az energiamentes édesítőszerek nem fokozzák a cukortartalmú, édes ízú élelmiszerek iránti vágyat, ső́t az újabb intervenciós vizsgálatokban ezek csökkent mértékű fogyasztását figyelték meg, amelynek következtében pozitív hatással lehetnek az étrend összetételére, valamint a súlykontrollra. Más területeken - mint például az édesítőszerek hatása a glükózanyagcserére, az oxidatív stresszre, valamint a zsírszövet metabolizmusára - jelen pillanatban még csupán ígéretes szövettenyészeteken végzett kutatások, illetve állatkísérleti eredmények állnak rendelkezésünkre.

Anyagi támogatás: A közlemény megírása anyagi támogatásban nem részesült.

Szerzöi munkamegosztás: Sz. Zs.: Az energiamentes édesítőszerek hatása az édes íz iránti vágyra; Az energiamentes édesítószerek fogyasztása és az étrend minősége címú fejezetek megírása. Á. T., L. G.: Az energiamentes édesítôszerek és az édes ízt érző receptorok; Az energiamentes édesítôszerek és az oxidativ stressz; Az energiamentes édesítőszerek és a zsírszövet című fejezetek megírása.
A szerzők a cikk végleges változatát elolvasták és jóváhagyták.

Érdekeltségek: A szerzőknek nincs érdekeltsége.

\section{Irodalom}

[1] Blundell, J. E., Hill, A. J.: Paradoxical effects of an intense sweetener (aspartame) on appetite. Lancet, 1986, 327(8489), 10921093.

[2] Blundell, J. E., Rogers, P. J., Hill, A. J.: Uncoupling sweetness and calories: methodological aspects of laboratory studies on appetite control. Appetite, 1988, 11(Suppl. 1), 54-61.

[3] Rogers, P. J., Blundell, J. E.: Separating the actions of sweetness and calories: Effects of saccharin and carbohydrates on hunger and food intake in human subjects. Physiol. Behav., 1989, 45(6), 1093-1099.

[4] Rogers, P. J., Blundell, J. E.: Intense sweeteners and appetite. Am. J. Clin. Nutr., 1993, 58(1), 120-122.

[5] Rogers, P. J., Carlyle, J. A., Hill, A. J., et al.: Uncoupling sweet taste and calories: Comparison of the effects of glucose and three intense sweeteners on hunger and food intake. Physiol. Behav., 1988, 43(5), 547-552.

[6] Bellisle, F.: Intense sweeteners, appetite for the sweet taste, and relationship to weight management. Curr. Obes. Rep., 2015, $4(1), 106-110$

[7] Mahar, A., Duizer, L. M.: The effect of frequency of consumption of artificial sweeteners on sweetness liking by women. J. Food Sci., 2007, 72(9), S714-S718.

[8] Disse, E., Bussier, A. L., Veyrat-Durebex, C., et al.: Peripheral ghrelin enhances sweet taste food consumption and preference, regardless of its caloric content. Physiol. Behav., 2010, 101(2), 277-281.

[9] Umabiki, M., Tsuzaki, K., Kotani, K., et al.: The improvement of sweet taste sensitivity with decrease in serum leptin levels during weight loss in obese females. Tohoku J. Exp. Med., 2010, 222(4), 267-271.

[10] Piernas, C., Tate, D. F., Wang, X., et al.: Does diet-beverage intake affect dietary consumption patterns? Results from the Choose Healthy Options Consciously Everyday (CHOICE) randomized clinical trial. Am. J. Clin. Nutr., 2013, 97(3), 604-611.

[11] Peters, J. C., Wyatt, H. R., Foster, G. D., et al.: The effects of water and non-nutritive sweetened beverages on weight loss during a 12-week weight loss treatment program. Obesity, 2014, 22(6), 1415-1421.

[12] De Ruyter, J. C., Katan, M. B., Kuijper, L. D., et al.: The effect of sugar-free versus sugar-sweetened beverages on satiety, liking and wanting: An 18 month randomized double-blind trial in children. PloS ONE, 2013, 8(10), e78039.

[13] Hercberg, S., Preziosi, P., Briançon, S., et al.: A primary prevention trial using nutritional doses of antioxidant vitamins and minerals in cardiovascular diseases and cancers in a general population: the SU.VI.MAX study - design, methods, and participant characteristics. Control. Clin. Trials, 1998, 19(4), 336-351.

[14] Drewnowski, A., Rehm, C. D.: Consumption of low-calorie sweeteners among U.S. adults is associated with higher healthy eating index (HEI 2005) scores and more physical activity. Nutrients, 2014, 6(10), 4389-4403.

[15] Piernas, C., Mendez, M. A., Ng, S. W., et al.: Low-calorie- and calorie-sweetened beverages: diet quality, food intake, and purchase patterns of US household consumers. Am. J. Clin. Nutr., 2014, 99(3), 567-577.

[16] Duffey, K. J., Steffen, L. M., Van Horn, L., et al.: Dietary patterns matter: diet beverages and cardiometabolic risks in the longitudinal Coronary Artery Risk Development in Young Adults (CARDIA) Study. Am. J. Clin. Nutr., 2012, 95(4), 909-915 
[17] Binkley, J., Golub, A.: Comparison of grocery purchase patterns of diet soda buyers to those of regular soda buyers. Appetite, 2007, 49(3), 561-571.

[18] Moran, A. W., Al-Rammahi, M. A., Arora, D K., et al.: Expression of $\mathrm{Na}+$ /glucose co-transporter l (SGLTl) is enhanced by supplementation of the diet of weaning piglets with artificial sweeteners. Br. J. Nutr., 2010, 104(5), 637-646.

[19] Stearns, A. T., Balakrishnan, A., Rhoads, D. B., et al.: Rapid upregulation of sodium-glucose transporter SGLTl in response to intestinal sweet taste stimulation. Ann. Surg., 2010, 251(5), 865-871.

[20] Margolskee, R. F., Dyer, J., Kokrashvili, Z., et al.: T1R3 and gustducin in gut sense sugars to regulate expression of $\mathrm{Na}+$-glucose cotransporter 1. Proc. Natl. Acad. Sci. U.S.A., 2007, 104(38), 15075-15080.

[21] Brown, R. J., Walter, M., Rother, K. I.: Ingestion of diet soda before a glucose load augments glucagon-like peptide-1 secretion. Diabetes Care, 2009, 32(12), 2184-2186.

[22] Steinert, R. E., Frey, F., Topfer, A., et al.: Effects of carbohydrate sugars and artificial sweeteners on appetite and the secretion of gastrointestinal satiety peptides. Br. J. Nutr., 2011, 105(9), $1320-1328$

[23] Ma, J., Bellon, M., Wishart, J. M., et al.: Effect of the artificial sweetener, sucralose, on gastric emptying and incretin hormone release in healthy subjects. Am. J. Physiol. Gastrointest. Liver Physiol., 2009, 296(4), G735-G739.

[24] Fujita, Y., Wideman, R. D., Speck, M., et al.: Incretin release from gut is acutely enhanced by sugar but not sweeteners in vivo. Am. J. Physiol. Endocrinol. Metab., 2009, 296(3), E473-E479.

[25] Cvijanovic, N., Feinle-Bisset, C., Young, R. L., et al.: Oral and intestinal sweet and fat tasting: impact of receptor polymorphisms and dietary modulation for metabolic disease. Nutr. Rev., $2015,73(5), 318-334$.
[26] Zheng, Y., Sarr, M. G.: Effect of the artificial sweetener, acesulfame potassium, a sweet taste receptor agonist, on glucose uptake in small intestinal cell lines. J. Gastrointest. Surg., 2013, $17(1), 153-158$.

[27] Sharma, R., Yadav, R., Manivannan, E.: Study of effect of Stevia rebaudiana Bertoni on oxidative stress in type- 2 diabetic rat models. Biomed. Aging Pathol., 2012, 2(3), 126-131.

[28] Shivanna, N., Naika, M., Khanum, F., et al.: Antioxidant, antidiabetic and renal protective properties of Stevia rebaudiana. J. Diabetes Complications, 2013, 27(2), 103-113.

[29] Abdel-Salam, O. M., Salem, N. A., Hussein, J. S.: Effect of aspartame on oxidative stress and monoamine neurotransmitter levels in lipopolysaccharide-treated mice. Neurotox. Res., 2012, 21(3), 245-255.

[30] Mitsutomi, K., Masaki, T., Shimasaki, T., et al.: Effects of nonnutritive sweetener on body adiposity and energy metabolism in mice with diet-induced obesity. Metabolism Clin. Exp., 2014, 63(1), 69-78.

[31] Zheng, J., Greenway, F. L., Heymsfield, S. B., et al.: Effects of three intense sweeteners on fat storage in the C. elegans model. Chem. Biol. Interact., 2014, 215, 1-6.

[32] Pandurangan, M., Park, J., Kim, E.: Aspartame downregulates 3T3-Ll differentiation. In Vitro Cell. Dev. Biol.-Animal, 2014, $50(9), 851-857$.

[33] Bhasker, S., Madhav, H., Chinnamma, M.: Molecular evidence of insulinomimetic property exhibited by steviol and stevioside in diabetes induced L6 and 3T3Ll cells. Phytomedicine, 2015, 22(11), 1037-1044.

(Szű́cs Zsuzsanna, Magyar Dietetikusok Országos Szövetsége, Budapest, Alig utca 4. 3/1., 1132 e-mail: szucs.zsuzsanna@gmail.com) 